\title{
Peningkatan Produktivitas Lahan Pertanaman Pepaya Sukma dengan Tanaman Sela Beberapa Jenis Sayuran
}

Land Productivity Improvement of Papaya Sukma in Alley Cropping with Several Vegetables

\author{
Dian Pratanda Rizki, Ketty Suketi ${ }^{*}$, dan Winarso Drajad Widodo
}

Departemen Agronomi dan Hortikultura, Fakultas Pertanian, Institut Pertanian Bogor

(Bogor Agricultural University), J1. Meranti, Kampus IPB Darmaga, Bogor 16680, Indonesia

Telp. \& Faks.62-251-8629353 e-mail agronipb@indo.net.id

*Penulis Korespondensi : kettysuketi@yahoo.com

Disetujui : 15 Januari 2018 / Published Online 23 Januari 2018

\begin{abstract}
Papaya (Carica papaya L.) is a fruit crop that has potential as a source of nutrition and canopy structure allows for planting alley cropping. Alley cropping is one way to increase land productivity. The purpose of this research to learn the land productivity improvement of papaya Sukma in alley cropping with several vegetable crops. This research was conducted at Tropical Horticulture Research Centre (PKHT) Pasir kuda, Ciomas and Postharvest Laboratory of the Department of Agronomy and Horticulture, Faculty of Agriculture, Bogor Agricultural University, February until July 2016. This research used a completely randomized design (CRD) with vegetable crops as treatments. The treatment consisted of 4 kinds of alley cropping and one control treatment. Alley cropping was used 1). Brassica rapa cv.caisin, 2). Amaranthus sp., 3). Ipomoea reptans, and 4). Basella alba. Alley cropping can increase land productivity. Alley cropping with Basella alba produced high vegetable production. Alley cropping with Amaranthus sp. produced high weight papaya fruit per plot whereas Ipomoea reptans produced lowest fruit weight. Alley cropping between the papaya plant did not affect growth, physical and chemical quality of papaya fruit.
\end{abstract}

Keywords : Amaranthus sp., Basella alba, Brassica rapa cv.caisin, Carica papaya L., Ipomoea reptans

\begin{abstract}
ABSTRAK
Pepaya (Carica papaya L.) merupakan tanaman buah yang berpotensi sebagai sumber gizi dan struktur tajuknya memungkinkan untuk ditanami tanaman sela. Penanaman tanaman sela (alley cropping) adalah salah satu cara untuk meningkatkan produktivitas lahan. Tujuan penelitian mempelajari peningkatan produktivitas lahan pertanaman pepaya Sukma dengan tanaman sela beberapa jenis sayuran. Percobaan dilaksanakan di kebun Pusat Kajian Hortikultura Tropika (PKHT) Pasir kuda, Ciomas dan Laboratorium Pascapanen Departemen Agronomi dan Hortikultura, Fakultas Pertanian, Institut Pertanian Bogor, sejak bulan Februari - Juli 2016. Percobaan ini menggunakan rancangan acak lengkap (RAL) dengan jenis tanaman sayuran sebagai perlakuan. Perlakuan terdiri atas 4 macam tanaman sela dan 1 perlakuan kontrol. Tanaman sela yang digunakan adalah 1). Caisin, 2). Bayam, 3). Kangkung, dan 4). Basella alba. Pola tanaman sela dapat meningkatkan produktivitas lahan. Perlakuan tanaman sela Basella alba menghasilkan produksi sayuran yang tinggi. Perlakuan tanaman sela bayam menghasilkan bobot buah pepaya per petak yang tinggi sedangkan tanaman kangkung menghasilkan bobot per buah pepaya terendah. Perlakuan tanaman sela di antara tanaman pepaya tidak mempengaruhi pertumbuhan, mutu fisik dan mutu kimia buah pepaya.
\end{abstract}

Kata kunci : Amaranthus sp., Basella alba, Brassica rapa cv.caisin, Carica papaya L., Ipomoea reptans 


\section{PENDAHULUAN}

Pepaya (Carica papaya L.) merupakan tanaman hortikultura yang banyak dibudidayakan. Tanaman pepaya sangat digemari dikalangan masyarakat Indonesia. Menurut Sujiprihati dan Suketi (2014) pepaya selain dikonsumsi untuk buah segar, buah pepaya matang juga dimanfaatkan sebagai bahan baku industri makanan dan minuman. Menurut Broto et al. (1991) buah pepaya juga merupakan sumber gizi yang penting terutama sebagai sumber vitamin $C$, A dan B kompleks. Berdasarkan data BPS (2015) produksi buah pepaya di Indonesia fluktuatif dari tahun 2012 sampai tahun 2014. Produksi pepaya pada tahun 2012 mencapai 906312 ton, pada tahun 2013 produksinya menjadi 909827 ton sedangkan pada tahun 2014 produksi pepaya mengalami penurunan menjadi 840119 ton. Keadaan produksi pepaya yang fluktuatif disebabkan kurangnya penggunaan varietas unggul dan ketersediaan lahan pertanian yang terbatas.

Menurut Mardhan (2015) luas lahan pertanian di Indonesia yang dimanfaatkan sebagai tanaman hortikultura terbatas jika dibandingkan dengan luas lahan untuk tanaman serealia atau tanaman perkebunan. Komoditas hortikultura memiliki nilai ekonomis yang tinggi dan budidayanya memerlukan tenaga kerja yang intensif. Tanaman hortikultura sangat sesuai dikembangkan dan diusahakan pada kondisi kepemilikan lahan yang terbatas seperti di Indonesia yang sebagian besar lahan pertaniannya digunakan untuk lahan perkebunan. Menurut Beets (1982) dibutuhkan teknik budidaya pertanian yang mampu meningkatkan efisiensi penggunaan lahan. Efisiensi penggunaan lahan usaha tani yang lebih produktif antara lain dengan mengusahakan beberapa jenis tanaman pada sebidang lahan yang sama. Teknik penanaman yang dapat dilakukan seperti tumpang sari (inter cropping), tanaman sela (alley cropping), dan tumpang gilir (multiple cropping). Jarak antar tanaman pepaya merupakan salah satu peluang untuk ditingkatkan produktivitasnya melalui penanaman komoditas lain sebagai tanaman sela.

Tanaman sela merupakan penanaman dua atau lebih tanaman yang tumbuh di sebidang lahan yang sama dengan pengaturan waktu tanam berbeda (Gomez dan Gomez, 1983). Perbedaan waktu tanam antara dua atau lebih jenis tanaman pada sebidang tanah dapat mengurangi persaingan dalam pemanfaatan hara, ruang atau tempat tumbuh dan air sehingga membantu usaha pencapaian potensi produksi kedua jenis tanaman yang ditumpang sarikan (Sarjoni, 2013). Tanaman sela kacang tanah dan kacang hijau tidak menjadi pesaing bagi tanaman lada perdu sebagai tanaman pokoknya dalam memanfaatkan sinar matahari karena habitus dan tajuk tanaman ini relatif lebih kecil dibandingkan tanaman pokoknya (Ferry dan Wardiana, 2012). Keadaan ini sesuai dengan komoditi sayuran yang digunakan sebagai tanaman sela bagi tanaman pepaya sebagai tanaman pokoknya. Menurut Sujiprihati dan Suketi (2014) keunggulan dari pepaya Sukma terletak pada daging buahnya yang berwarna merah. Warna kulit hijau tua dan ketika matang ada semburat kuning di ujung buahnya sehingga terlihat eksotik. Bobotnya mencapai $2.8 \mathrm{~kg}$ dan cocok untuk konsumsi keluarga besar. Kadar manis daging buahnya mencapai $10-11^{0}$ brix dengan umur petiknya sekitar 140-150 hari setelah antesis (bunga mekar).

Penanaman tumpang sari antara tanaman jagung dengan kacang panjang lebih efisien dalam penggunaan lahan pertanian dibandingkan dengan pola tanam monokultur (Mongdong, 2007). Manfaat penerapan tanaman sela tidak berbeda dengan pola tanam tumpang sari. Manfaat penanaman tanaman sela ialah dapat meningkatkan produktivitas dan hasil, efisien dalam pemanfaatan sumberdaya pertanian (lahan, tenaga kerja, waktu, cahaya, air, dan hara), dapat mengurangi kehilangan hasil karena hama, penyakit dan gulma serta dapat meningkatkan manfaat sosial dan ekonomi yang meliputi stabilitas produksi, ekonomi, nutrisi dan ekologi (Jensen et al., 2006). Penelitian ini bertujuan untuk mempelajari produktivitas lahan tanaman pepaya Sukma dengan beberapa jenis sayuran sebagai tanaman sela.

\section{METODE PENELITIAN}

Penelitian dilaksanakan di kebun Pusat Kajian Hortikultura Tropika (PKHT) Pasir kuda Ciomas dan Laboratorium Pascapanen Departemen Agronomi dan Hortikultura, Fakultas Pertanian, Institut Pertanian Bogor pada bulan Februari 2016 hingga bulan Juli 2016. Bahan utama yang digunakan dalam penelitian ini adalah tanaman pepaya Sukma dan berbagai jenis benih sayuran (caisin, bayam dan kangkung) serta bibit tanaman Basela alba. Bahan yang digunakan untuk perlakuan yaitu furadan (karbofuran 3\%), pupuk kandang, kapur pertanian, pupuk NPK, pestisida, desinfektan Natrium Hipoklorit, akuades, indikator phenolphthalein (PP), larutan $\mathrm{NaOH} 0.1 \mathrm{~N}$, iodine $0.01 \mathrm{~N}$, amilum, kertas koran dan kain saring. Alat-alat yang digunakan dalam penelitian ini adalah alat-alat pertanian, knapsack sprayer, hand traktor, timbangan, paranet, 
penetrometer, hand refraktometer, termometer, labu takar, labu erlemeyer, buret, timbangan analitik, label dan kamera.

Penelitian ini dilaksanakan dengan menggunakan rancangan acak lengkap (RAL) dengan faktor tunggal pada masing-masing jenis tanaman sayuran. Perlakuan terdiri dari 5 macam, yaitu 1). Tanpa tanaman sela sebagai kontrol, 2). Caisin, 3). Bayam, 4). Kangkung, dan 5). Basela alba. Setiap perlakuan terdiri dari 3 ulangan sehingga terdapat 15 satuan percobaan. Prosedur penelitian yang dilakukan dibagi atas dua tahapan. Tahap pertama yaitu prosedur penelitian tanaman pepaya terdiri dari penandaan (tagging) bunga mekar sempurna (antesis) sebanyak 10-20 bunga dan persiapan buah. Bunga yang telah ditandai diberi label. Metode ini mengacu pada penelitian Taris et al. (2014), Sugito (2015) dan Putri (2016). Persiapan buah dilakukan pada saat buah pepaya telah dipanen. Buah pepaya yang telah dipanen disortasi kemudian dicuci dengan menggunakan desinfektan Natrium Hipoklorit dengan konsentrasi $10 \%$ untuk mengendalikan cendawan. Pepaya yang sudah dicuci dikering anginkan dengan diberi alas. Penyimpanan pada suhu berkisar $25-30{ }^{\circ} \mathrm{C}$ dengan kelembaban $70-80$ $\%$.

Persiapan dan pengolahan lahan dilakukan 2 minggu sebelum penanaman. Kegiatan persiapan dan pengolahan lahan meliputi pembalikan tanah menggunakan handtraktor, pembuatan bedengan dan pembersihan lahan dari gulma. Jarak tanam pepaya Sukma yang digunakan selama percobaan adalah $3 \mathrm{~m} \times 3 \mathrm{~m}$ dengan luas lahan sebesar $810 \mathrm{~m}^{2}$. Bedengan yang dibuat diantara tanaman pepaya Sukma berukuran $5 \mathrm{~m}$ x $1 \mathrm{~m}$. Menurut Balitsa (2007) pemberian pupuk kandang untuk tanaman caisin, bayam dan kangkung sebanyak 10 ton/ha atau setara dengan $5 \mathrm{~kg} / 5 \mathrm{~m}^{2}$. Menurut Widati dan Hidayat (2012) pemberian pupuk kandang untuk tanaman Basella alba sebanyak 20 ton/ha atau setara dengan 10 $\mathrm{kg} / 5 \mathrm{~m}^{2}$. Penanaman kangkung dilakukan dengan sistem tugal, setiap lubang tanam ditanami dengan 2 butir benih kangkung pada jarak tanam $15 \mathrm{~cm} \mathrm{x}$ $5 \mathrm{~cm}$. Bayam ditanam dalam alur dengan jarak antar baris $20 \mathrm{~cm}$ mengacu pada Balitsa (2007). Tanaman caisin sebelum ditanam di lahan, disemai terlebih dahulu pada media tanam. Bibit caisin ditanam di lahan saat bibit berumur 3-4 minggu, atau setelah memiliki 3-5 helai daun. Jarak tanam yang digunakan yaitu $20 \mathrm{~cm}$ x $20 \mathrm{~cm}$ dengan satu lubang tanam satu bibit mengacu pada Susila (2006). Basella alba sebelum ditanam di lahan, disemai terlebih dahulu pada media pupuk kandang dan kompos dengan perbandingan 1 : 2 pada polibag kecil atau tray. Perbanyakan tanaman dengan menggunakan stek batang. Tanaman B. alba siap dipindahkan ke lahan setelah memiliki empat daun. Jarak tanam yang digunakan yaitu $80 \mathrm{~cm}$ x $50 \mathrm{~cm}$ mengacu pada Widati dan Hidayat (2012).

Penanaman benih caisin, bayam dan kangkung disertai dengan pemberian insektisida karbofuran mengacu pada Balitsa (2007). Dosis pupuk yang digunakan untuk tanaman caisin, bayam dan kangkung yaitu $250 \mathrm{~kg} / \mathrm{ha}$ urea, 100 $\mathrm{kg} / \mathrm{ha}$ SP-36 dan $150 \mathrm{~kg} / \mathrm{ha} \mathrm{KCl}$. Pemeliharaan tanaman yang dilakukan meliputi penyiraman, pemupukan kedua dan pengendalian organisme pengganggu tanaman. Pemupukan kedua menggunakan pupuk NPK yang diberikan dalam bentuk cairan dengan cara melarutkan $200 \mathrm{~g}$ pupuk/plot dalam 101 air mengacu pada Susilo dan Diennazola (2012). Pemupukan Basella alba dilakukan pada saat 10, 20, 30, 40, 50, dan 60 hari setelah tanam (HST) yaitu berupa pupuk NPK dengan dosis $60 \mathrm{~kg} / \mathrm{ha}$. B. alba memerlukan trellis atau gelagar sebagai penopang untuk menunjang pertumbuhan yang baik, karena karakter tumbuhnya yang merambat mengacu pada Widati dan Hidayat (2012). Kegiatan pemupukan pada tanaman pepaya Sukma tidak dilakukan sejak awal sampai akhir percobaan. Pemupukan hanya dilakukan pada tanaman sayuran yang ditanam di antara tanaman pepaya. Pengendalian gulma dilakukan secara manual setiap minggu serta dilakukan pengendalian hama dan penyakit secara kimiawi.

Pemanenan dilakukan pada saat tanaman caisin, bayam dan kangkung berumur 20-30 HST (Susilo dan Diennazola, 2012). Pemanenan caisin, bayam dan kangkung dengan cara mencabut seluruh tanaman beserta akarnya mengacu pada Susila (2006). B. alba dapat dipanen 30-45 HST. Panen dapat dilakukan beberapa kali dalam interval 1 minggu dengan memotong pucuk muda sepanjang $20 \mathrm{~cm}$ mengacu pada Widati dan Hidayat (2012). Buah pepaya IPB dipanen pada stadia kematangan yang ditunjukkan dengan warna kuning pada kulit buah $25 \%$ (stadia II) (Suketi et al., 2010a). Pemanenan buah pepaya IPB 6C dilakukan pada saat buah memiliki semburat kira-kira 20-25\% (Fardilawati, 2008). Pemanenan buah pepaya Sukma selama penelitian dilakukan berdasarkan satuan panas. Nilai satuan panas yang digunakan untuk pemanenan buah pepaya selama penelitian sebesar $2100{ }^{\circ} \mathrm{C}$ hari. Pemanenan pepaya Sukma dan akhir penanaman sayuran dilakukan ketika suhu mencapai $2100{ }^{\circ} \mathrm{C}$ hari. Pengamatan dilakukan pada tanaman sayuran dan tanaman pepaya Sukma. Peubah pengamatan sayuran meliputi persentase daya tumbuh dan produksi tanaman sayuran. Peubah pengamatan 
pertumbuhan, produksi dan pasca penen buah pepaya Sukma meliputi satuan panas, panjang dan lingkar buah untuk mendapatkan data diameter buah menggunakan rumus $\mathrm{K}=\pi \mathrm{d}$, produksi tanaman pepaya Sukma, susut bobot, warna kulit, kekerasan kulit dan daging buah, padatan terlarut total (PTT), asam tertitrasi total (ATT) serta kandungan vitamin $\mathrm{C}$.

Data yang diperoleh dianalisis untuk mengetahui pengaruh dari perlakuan dengan menggunakan analisis ragam (uji F). Hasil uji F menunjukkan pengaruh nyata, maka dilakukan uji BNJ pada taraf $5 \%$.

\section{HASIL DAN PEMBAHASAN}

\section{Pertumbuhan Tanaman Sayuran}

Persentase daya tumbuh tanaman sayuran 1 MST pada saat penanaman pertama yaitu caisin $82.50 \%$, bayam $71.00 \%$, kangkung $93.40 \%$ dan Basella alba $100 \%$ sedangkan pada saat penanaman kedua yaitu caisin $98.75 \%$, bayam $52.88 \%$, kangkung $90.07 \%$ dan Basella alba $100 \%$. Persentase daya tumbuh tanaman bayam terendah dibandingkan dengan tanaman lainnya diduga karena vigor benih yang rendah. Menurut Suwarno dan Hapsari (2008) tingkat viabilitas benih dikategorikan tinggi jika daya berkecambah $>85 \%$ dan rendah $<75 \%$. Selain itu, keadaan iklim tidak mempengaruhi pertumbuhan tanaman sayuran untuk tumbuh subur. Menurut Setiawati et al. (2007) tanaman sayuran pada umumnya tidak memiliki syarat tumbuh yang khusus. Syarat tumbuh yang terpenting adalah ketersediaan air

Tabel 1. Produksi tanaman sayuran per $5 \mathrm{~m}^{2}$ yang cukup, tanah gembur dan cukup subur. Waktu tanam yang terbaik adalah pada awal musim hujan antara bulan Oktober-November atau pada awal musim kemarau antara bulan Maret-April.

\section{Produksi Tanaman Sayuran dan Pepaya}

Perlakuan tanaman Basella alba menunjukkan produksi total yang tinggi sebesar $19.36 \mathrm{~kg} / 5 \mathrm{~m}^{2}$. Perlakuan tanaman caisin menunjukkan produksi total yang rendah sebesar $6.17 \mathrm{~kg} / 5 \mathrm{~m}^{2}$ (Tabel 1). Pemupukan tanaman sayuran caisin, bayam dan kangkung hanya dilakukan 1 kali pada saat penanaman pertama sedangkan penanaman kedua tidak dilakukan pemupukan kembali. Pemupukan Basella alba dilakukan sebanyak 6 kali dengan interval waktu yang telah ditentukan. Selain itu, tedapat kendala dalam penanaman lanjutan untuk tanaman caisin, bayam dan kangkung yang seharusnya dapat ditanam 3 kali hanya dapat ditanam 2 kali disebabkan kurangnya tenaga kerja sementara tanaman Basella alba dari panen I sampai akhir penelitian tetap menghasilkan produksi. Kondisi ini menyebabkan produksi dari tanaman Basella alba lebih tinggi dibandingkan dengan tanaman sayuran lainnya. Struktur tajuk tanaman pepaya memungkinkan untuk ditanami tanaman sela. Struktur tajuk yang dimiliki oleh tanaman pepaya mempengaruhi produksi tanaman sela yang digunakan. Hal ini menunjukkan bahwa produksi tanaman sela dapat meningkatkan produktivitas lahan pertanaman pepaya Sukma.

\begin{tabular}{lcccc}
\hline Perlakuan & Panen I $(\mathrm{kg})$ & Panen II $(\mathrm{kg})$ & Produksi total $(\mathrm{kg})$ & $\begin{array}{c}\text { Produksi per bulan } \\
(\mathrm{kg})\end{array}$ \\
\hline Kontrol* & - & - & - & - \\
Caisin & 2.23 & 3.94 & 6.17 & 3.09 \\
Bayam & 4.90 & 2.45 & 7.35 & 3.68 \\
Kangkung & 3.05 & 3.15 & 6.20 & 3.10 \\
Basella & 9.58 & 9.78 & 19.36 & 9.68 \\
\hline
\end{tabular}

Keterangan: *perlakuan kontrol tidak ditanamin sayuran (tidak ada panen)

Tanaman sela yang berpotensi meningkatkan produktivitas lahan pepaya Sukma selama penelitian adalah tanaman Basella alba, bayam, kangkung dan caisin. Produksi tanaman sayuran dapat dilihat pada Lampiran 3. Menurut Poerwanto dan Susila (2013) pemupukan adalah tindakan penambahan hara ke dalam tanah apabila tanah tersebut tidak mampu mendukung ketersediaan hara untuk mendukung pertumbuhan tanaman secara maksimum. Menurut Fauziah
(2011) bobot panen caisin dengan pemberian pupuk organik 2 ton/ha dan pupuk anorganik 75\% dari (200 kg urea/ha, $300 \mathrm{~kg} \mathrm{SP}-36 / \mathrm{ha}$ dan $100 \mathrm{~kg}$ $\mathrm{KCl} / \mathrm{ha}$ ) sebesar $8.06 \mathrm{~kg} / 5 \mathrm{~m}^{2}$. Menurut Nirmalayanti (2017) bobot panen bayam merah dengan pemberian kombinasi pupuk kandang 5 ton/ha dan $1 / 2$ pupuk kimia ( 5 ton $+50 \mathrm{~kg}$ Phonska $+50 \mathrm{~kg}$ urea) per ha diperoleh sebesar $2.43 \mathrm{~kg} / 4$ $\mathrm{m}^{2}$. Menurut Muntashilah (2015) bobot panen kangkung darat dengan pemberian pupuk kandang 
5 ton/ha dan urea $150 \mathrm{~kg} / \mathrm{ha}$ diperoleh sebesar $3.61 \mathrm{~kg} / 2 \mathrm{~m}^{2}$.

Perlakuan tanaman sela tidak mempengaruhi jumlah buah dipanen dan bobot buah per petak tetapi mempengaruhi bobot per buah pepaya Sukma. Kondisi tanaman pepaya yang tidak dilakukan pemupukan selama percobaan masih dapat memberikan produksi

Tabel 2. Produksi tanaman pepaya sukma
(Tabel 2). Perlakuan tanaman bayam menunjukkan bobot buah per petak yang tinggi sebesar $5.04 \mathrm{~kg}$ sedangkan perlakuan tanaman kangkung menunjukkan bobot buah per petak yang rendah sebesar $3.20 \mathrm{~kg}$. Perlakuan tanaman kangkung menunjukkan bobot per buah terendah sebesar sebesar $1.60 \mathrm{~kg}$ dibandingkan dengan perlakuan lainnya.

\begin{tabular}{lccc}
\hline Perlakuan & $\begin{array}{c}\text { Jumlah buah dipanen } \\
\text { per petak }\end{array}$ & $\begin{array}{c}\text { Bobot buah per petak } \\
(\mathrm{kg})\end{array}$ & Bobot per buah $(\mathrm{kg})$ \\
\hline Kontrol & 2 & 4.62 & $2.58 \mathrm{a}$ \\
Caisin & 2 & 4.29 & $2.15 \mathrm{ab}$ \\
Bayam & 3 & 5.04 & $1.91 \mathrm{ab}$ \\
Kangkung & 2 & 3.20 & $1.60 \mathrm{~b}$ \\
Basella & 2 & 4.33 & $1.84 \mathrm{ab}$ \\
\hline
\end{tabular}

Keterangan: Angka yang diikuti huruf berbeda pada kolom yang sama berbeda nyata menurut BNJ pada taraf $\alpha=5 \%$

Keadaan tanaman pepaya pada saat penelitian setelah dilakukan penandaan bunga mekar terdapat bunga sampel gugur sebelum pembuahan selain itu terdapat buah sampel yang gugur disebabkan oleh penyakit seperti antraknosa. Hal ini diduga sebagai penyebab rendahnya produksi pepaya. Kondisi iklim di lokasi penelitian merupakan salah satu penyebab rendahnya produksi buah pepaya karena curah hujan yang tinggi dan angin yang kencang yang menyebabkan beberapa tanaman sampel tumbang sehingga mengurangi produksi. Berdasarkan BMKG Dramaga (2016) rata-rata curah hujan dari bulan Maret-Juli 2016 sebesar $343.8 \mathrm{~mm} / \mathrm{bulan}$ (Lampiran 4). Menurut Barus dan Syukri (2008) curah hujan yang sesuai untuk pertanaman pepaya berkisar antara $1500-2000 \mathrm{~mm} /$ tahun atau setara dengan 125-166.7 mm/bulan. Hasil penelitian Hafsah et al. (2007) perbedaan ketinggian, suhu dan kelembaban yang mempengaruhi tingkat ketahanan pepaya IPB 1 terhadap penyakit antraknosa.

\section{Pertumbuhan Buah Pepaya}

Tanaman sela tidak mempengaruhi pertumbuhan panjang dan diameter buah pepaya. Pertumbuhan panjang buah pepaya setiap perlakuan mengalami peningkatan setiap minggunya. Hal ini juga terjadi pada pertumbuhan diameter buah pepaya. Panjang buah rata-rata mencapai $35 \mathrm{~cm}$ sedangkan diameter mencapai $11-12 \mathrm{~cm}$ (Gambar 2). Buah pepaya Sukma merupakan tipe buah berukuran besar. Keadaan ini diduga karena perbedaan dalam pemeliharaan dan kondisi lingkungan saat penelitian sehingga memberikan perbedaan terhadap pertumbuhan buah pepaya Sukma. Pertumbuhan diameter buah pepaya Sukma mempunyai pola yang sama dengan pertumbuhan panjang buah (Gambar 2). Menurut Khumairot (2014) pola tanam tumpang sari antara tanaman tomat dengan jagung tidak mempengaruhi pertumbuhan dan produksi jagung. Hasil penelitian Fardilawati (2008) panjang buah pepaya IPB 6C mencapai $29.20-31.84 \mathrm{~cm}$ dan diameter tengah mencapai 11.34-12.13 cm. Menurut Sujiprihati dan Suketi (2014) panjang buah pepaya Sukma mencapai $15-18 \mathrm{~cm}$ dan diameter tengah mencapai $13.4 \mathrm{~cm}$. Menurut Ryall dan Pentzer (1982) setelah periode pembelahan sel, perkembangan utama pada buah ialah pembesaran ukuran sel yang akan membentuk daging buah dimana ruang interseluler akan terbentuk sehingga sel-sel tersebut akan memperbesar ukuran buah dan buah akan memanjang. 


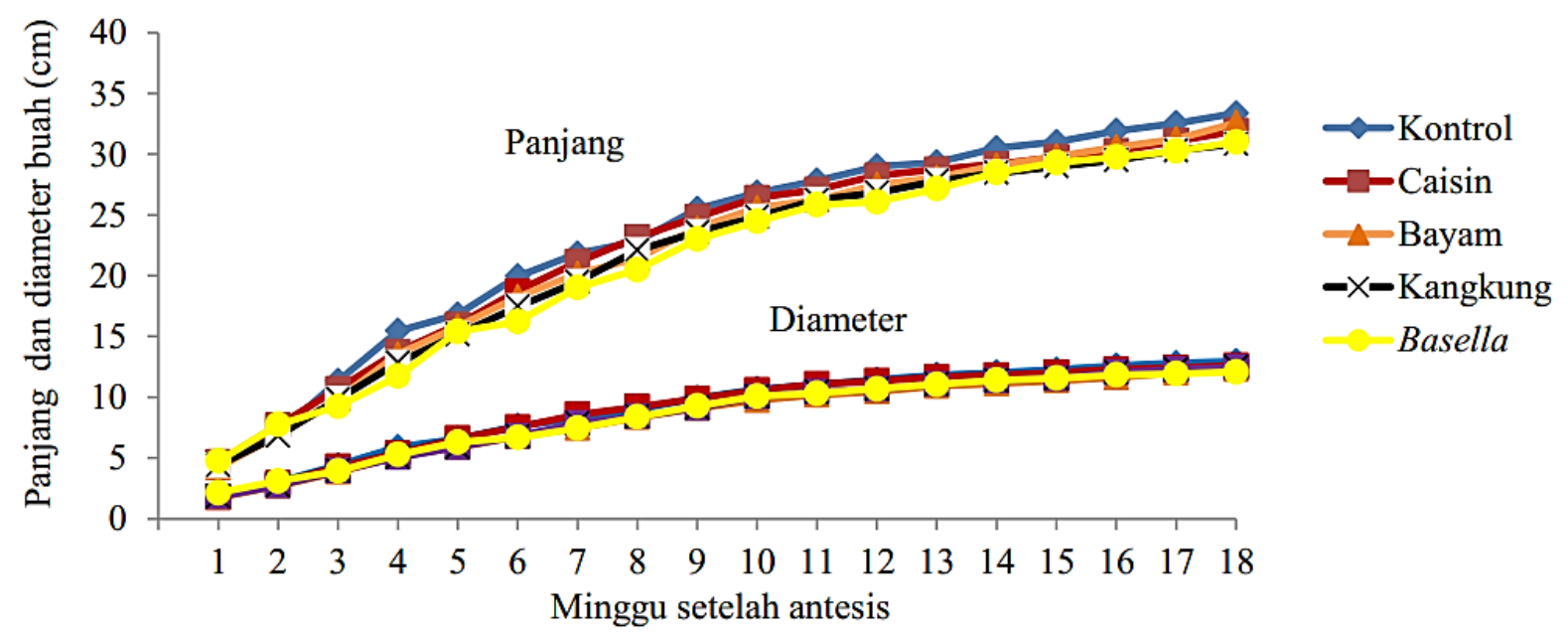

Gambar 1. Pertumbuhan panjang dan diameter buah pepaya Sukma

\section{Susut Bobot dan Umur Simpan Buah Pepaya}

Tanaman sela mempengaruhi susut bobot buah. Nilai susut bobot yang tertinggi pada perlakuan tanaman sela kangkung sebesar $7.99 \%$ dan rendah pada perlakuan kontrol sebesar $4.15 \%$ (Tabel 3). Hasil penelitian Putri (2016) susut bobot pepaya Sukma sebesar 4.88 sampai $8.48 \%$. Menurut Normasari dan Purwoko (2002) susut bobot buah tomat naik selama penyimpanan. Susut bobot terjadi sebagai akibat dari kehilangan air buah tomat karena proses penguapan dan kehilangan karbon selama respirasi. Menurut
Deell et al. (2003) penurunan bobot buah disebabkan terjadinya transpirasi. Proses transpirasi adalah penyebab utama kehilangan panen dan penurunan kualitas buah. Menurut Kader (1992) kehilangan air akibat proses respirasi dan transpirasi pada buah merupakan penyebab utama proses deteriorasi karena berpengaruh secara kualitatif maupun kuantitatif pada umur simpan buah. Pengaruh secara kuantitatif yaitu susut bobot. Susut bobot buah semakin meningkat dengan bertambahnya waktu penyimpanan.

Tabel 3. Bobot awal, bobot akhir, susut bobot, dan umur simpan buah pepaya Sukma

\begin{tabular}{lcccc}
\hline Tanaman Sela & Bobot awal $(\mathrm{g})$ & Bobot akhir $(\mathrm{g})$ & Susut bobot $(\%)$ & $\begin{array}{c}\text { Umur simpan } \\
(\mathrm{HSP})\end{array}$ \\
\hline Kontrol & 2310.50 & 2214.67 & $4.15 \mathrm{~b}$ & 3.75 \\
Caisin & 2146.33 & 2042.83 & $4.82 \mathrm{~b}$ & 3.50 \\
Bayam & 2103.83 & 1996.83 & $5.09 \mathrm{~b}$ & 4.83 \\
Kangkung & 1601.83 & 1473.83 & $7.99 \mathrm{a}$ & 4.75 \\
Basella & 1950.83 & 1847.00 & $5.32 \mathrm{~b}$ & 4.08 \\
\hline
\end{tabular}

Keterangan: Angka yang diikuti huruf berbeda pada kolom yang sama berbeda nyata menurut BNJ pada taraf $\alpha=5 \%$; HSP: hari setelah panen

Tanaman sela tidak mempengaruhi umur simpan buah. Umur simpan buah pepaya Sukma selama penelitian relatif singkat sebesar 3.50 sampai 4.83 HSP. Pengamatan umur simpan buah dilakukan setelah buah dipanen sampai buah mencapai skala warna 6. Skala warna kulit buah dapat dilihat pada Gambar 2. Menurut Suketi et al. (2015) indeks skala warna > 4 dijadikan acuan dalam menentukan umur simpan buah. Hal ini berdasarkan bahwa buah pepaya dengan indeks skala warna > 4 telah mencapai matang yang layak jual dan konsumsi. Penggunaan acuan skala warna > 4 disebabkan adanya infeksi cendawan yang berkembang cepat ketika mencapai indeks warna tersebut sehingga berkurangnya umur simpan buah. Pantastico (1989) menyatakan bahwa buah yang masih berwarna hijau biasanya masih mengandung banyak klorofil, kemudian perlahan akan berubah warna menjadi kuning yang menandakan bahwa kandungan klorofil yang terdapat dalam buah tersebut sudah berkurang selama pematangan dan mulai munculnya zat warna karotenoid. 


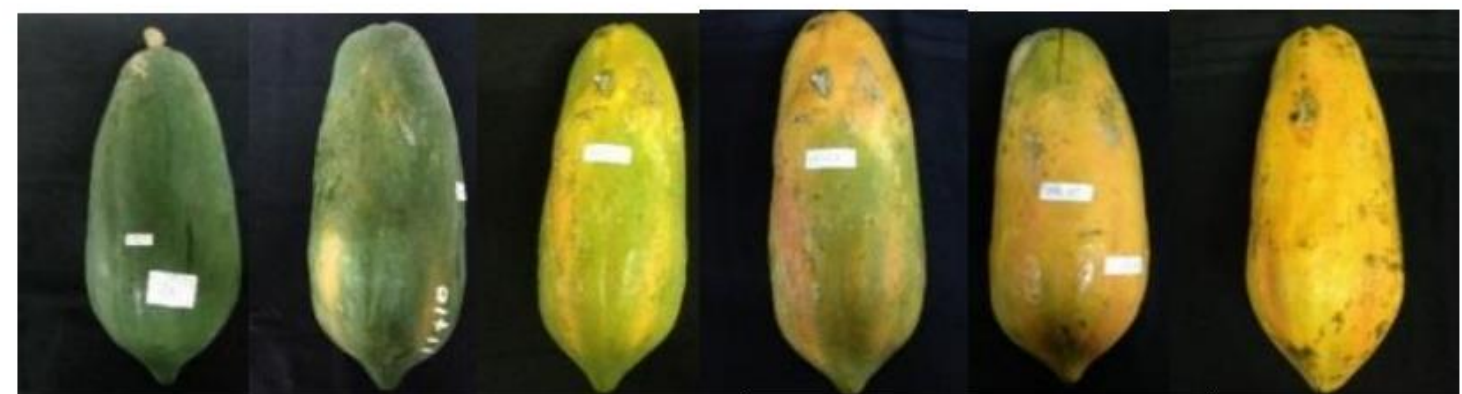

(1)

(2)

(3)

(4)

(5)

(6)

Gambar 2. Keragaan buah pepaya Sukma pada 6 skala. (1) Hijau, (2) Hujau dengan sedikit kuning, (3) Hijau kekuningan, (4) Kuning lebih banyak dari hijau, (5) Kuning dengan ujung sedikit hijau, (6) Kuning penuh

Berdasarkan nilai umur simpan yang diperoleh dengan satuan panas sebesar $2100{ }^{\circ} \mathrm{C}$ merupakan kondisi yang baik untuk pemasaran produk yang waktu pemasarannya singkat dengan waktu transportasi kurang dari 4 hari. Hasil penelitian Putri (2016) pepaya Sukma di Pasir Kuda pada bulan Maret sampai Juli 2015 memiliki curah hujan yang tinggi sebesar $426.6 \mathrm{~mm}$ dan suhu $25.3{ }^{\circ} \mathrm{C}$ dengan umur simpan sebesar 9.00 HSP pada satuan panas $2269.80{ }^{\circ} \mathrm{C}$ hari sedangkan pada satuan panas $1967.03{ }^{\circ} \mathrm{C}$ hari memiliki umur simpan sebesar 12.7 HSP. Semakin tinggi nilai satuan panas yang digunakan, maka semakin singkat umur simpan buah pepaya Sukma. Hasil penelitian Fardilawati (2008) pepaya IPB 6C di Pasir Kuda pada bulan Nopember 2007 sampai Februari 2008 memiliki curah hujan sebesar 292.4-475.2 mm/bulan dengan umur simpan buah sebesar 3.48-3.85 HSP. Hasil penelitian Taris et al. (2014) pepaya Callina dengan satuan panas sebesar $2241.75{ }^{0} \mathrm{C}$ hari memiliki daya simpan yang singkat sebesar 4.08 HSP. Faktor iklim yaitu suhu mempengaruhi umur simpan dan kualitas buah. Semakin tinggi satuan panas yang diperoleh maka semakin tua umur petik pepaya Callina, sehingga mempengaruhi umur simpan. Menurut Mardiana (2003) rata-rata umur simpan buah pepaya adalah 3-5 hari sebelum buah akhirnya rusak akibat telah lewat matang ataupun busuk karena serangan cendawan.

\section{Mutu Fisik Buah Pepaya}

Mutu fisik merupakan kondisi utama yang dinilai para konsumen untuk dikonsumsi. Mutu fisik buah pepaya yang diamati meliputi kelunakan daging, kekerasan kulit dan edible portion pada saat kulit buah pepaya telah mencapai skala 6. Informasi data mutu fisik dapat dilihat pada Tabel 4.

Tabel 4. Kualitas fisik buah pepaya Sukma pada skala warna 6

\begin{tabular}{lccc}
\hline Tanaman Sela & $\begin{array}{c}\text { Kelunakan daging buah } \\
(\mathrm{mm} / \mathrm{g} / \mathrm{detik})\end{array}$ & $\begin{array}{c}\text { Kekerasan kulit buah } \\
(\mathrm{mm} / \mathrm{g} / \mathrm{detik})\end{array}$ & $\begin{array}{c}\text { Bagian yang dapat dimakan } \\
(\text { Edible portion })(\%)\end{array}$ \\
\hline Kontrol & 0.29 & 0.24 & 86.46 \\
Caisin & 0.33 & 0.22 & 85.43 \\
Bayam & 0.29 & 0.15 & 85.89 \\
Kangkung & 0.37 & 0.20 & 83.94 \\
Basella & 0.30 & 0.16 & 87.67 \\
\hline
\end{tabular}

Perlakuan tanaman sela tidak mempengaruhi kualitas fisik buah pepaya Sukma seperti kelunakan daging, kekerasan kulit dan edible portion pada skala kematangan yang sama. Berdasarkan data yang diperoleh nilai kelunakan daging sebesar 0.29 sampai $0.37 \mathrm{~mm} / \mathrm{g} /$ detik dan nilai kekerasan kulit buah sebesar 0.15 sampai $0.24 \mathrm{~mm} / \mathrm{g} /$ detik. Penelitian Putri (2016) menunjukkan satuan panas yang berbeda tidak mempengaruhi nilai kelunakan daging dan kelunakan kulit pepaya Sukma sebesar 0.24 sampai $0.30 \mathrm{~mm} / \mathrm{g} / \mathrm{detik}$ dan 0.12 sampai 0.17 $\mathrm{mm} / \mathrm{g} /$ detik pada kematangan pascapanen yang sama. Pengamatan pascapanen pada tingkat kematangan yang sama mempengaruhi kelunakan daging dan kekerasan kulit buah tidak berbeda antar umur panen. Hasil penelitian Taris et al. (2014) menunjukkan buah pepaya Callina dengan umur panen yang berbeda (115-130 HSA) tidak mempengaruhi nilai kelunakan kulit buah 0.12- 
$0.13 \mathrm{~mm} / \mathrm{g} /$ detik dan nilai kelunakan daging buah $0.36-0.38 \mathrm{~mm} / \mathrm{g} /$ detik. Menurut Suketi et al. (2010a) buah yang dipanen pada jumlah hari setelah antesis berbeda, ada yang menunjukkan keragaan warna kulit buah yang sama dan diduga mempunyai tingkat kematangan buah yang sama pula sehingga menyebabkan kekerasan kulit buah pada ketiga stadia kematangan tidak berbeda.

$$
\text { Perlakuan tanaman sela tidak }
$$

mempengaruhi edible portion. Edible portion sebesar $83-87 \%$ dengan bobot saat panen 1.60 sampai $2.31 \mathrm{~kg}$. Bobot saat panen juga diduga mempengaruhi hasil pengukuran edible portion. Hal ini dapat dikatakan buah pepaya Sukma hasil penelitian dapat memenuhi nilai konsumsi konsumen. Menurut Putri (2016) bobot buah pepaya Sukma saat panen berkisar antara 1.28 sampai $1.48 \mathrm{~kg}$ dengan persentase edible portion 70.13 sampai $76.37 \%$. Hasil penelitian Fardilawati (2008) menunjukkan pepaya Sukma memiliki edible portion yang tinggi sebesar 77.89 sampai $79.01 \%$ dengan bobot saat panen berkisar 1.65 sampai $1.94 \mathrm{~kg}$.

\section{Mutu Kimia Buah Pepaya}

Mutu kimia merupakan salah satu yang mempengaruhi kelayakan konsumsi dan keinginan konsumen. Mutu kimia mempengaruhi kualitas rasa, aroma dan kandungan gizi buah. Mutu kimia buah pepaya meliputi padatan terlarut total (PTT), asam tertitrasi total (ATT), rasio PTT/ATT dan kandungan vitamin $\mathrm{C}$ pada saat kulit buah pepaya telah mencapai skala 6 (Tabel 5).

Tabel 5. Kualitas kimia buah pepaya Sukma pada skala warna 6

\begin{tabular}{lcccc}
\hline Tanaman Sela & $\begin{array}{c}\text { Padatan terlarut } \\
\text { Total }\left({ }^{\circ} \text { Brix }\right)\end{array}$ & $\begin{array}{c}\text { Asam tertitrasi total } \\
(\mathrm{mg} / 100 \mathrm{~g})\end{array}$ & Rasio PTT/ATT & $\begin{array}{c}\text { Kandungan vitamin C } \\
(\mathrm{mg} / 100 \mathrm{~g})\end{array}$ \\
\hline Kontrol & 9.92 & 2.93 & 4.15 & 129.26 \\
Caisin & 10.23 & 2.33 & 4.48 & 134.35 \\
Bayam & 9.43 & 5.47 & 3.72 & 98.68 \\
Kangkung & 9.82 & 3.13 & 4.88 & 121.09 \\
Basella & 10.15 & 3.15 & 3.68 & 130.94 \\
\hline
\end{tabular}

Perlakuan tanaman sela tidak mempengaruhi kualitas kimia buah pepaya Sukma. Hasil pengukuran padatan terlarut total dengan satuan panas $2100{ }^{\circ} \mathrm{C}$ hari sebesar 9.4310.23 brix. Hasil penelitian Putri (2016) kandungan padatan terlarut total pepaya Sukma tertinggi pada satuan panas $2269.80{ }^{\circ} \mathrm{C}$ hari (11.88 ${ }^{\circ}$ brix) sedangkan kandungan padatan terlarut total terendah pada satuan panas 1967.03 ${ }^{0} \mathrm{C}$ hari (9.9 ${ }^{0}$ brix). Semakin tinggi nilai akumulasi satuan panas yang diperoleh menyebabkan kemanisan buah meningkat. Menurut Suketi et al. (2010a) nilai PTT buah semakin meningkat dengan bertambahnya stadia kematangan buah.

Hasil pengukuran asam tertitrasi total (ATT) sebesar 2.33 sampai $5.47 \mathrm{mg} / 100 \mathrm{~g}$ bahan. Rasio PTT/ATT pepaya Sukma yang diamati berkisar antara 3.68-4.88. Hasil percobaan menunjukkan bahwa nilai ATT berbanding lurus dengan nilai PTT. Menurut Pratiwi et al. (2014) rasio PTT/ATT merupakan perbandingan nilai gula dan asam yang terkandung dalam buah, semakin besar nilai rasio PTT/ATT maka buah semakin manis. Menurut Suketi et al. (2007) semakin besar kandungan ATT maka nilai rasio perbandingan PTT/ATT semakin kecil. Semakin tinggi nilai PTT, nilai ATT semakin tinggi. Hasil penelitian Putri (2016) nilai ATT pepaya Sukma sebesar 0.08 sampai $0.11 \%$. Hasil penelitian Putri
(2016) nilai ATT pepaya Sukma sebesar 0.08 sampai 0,11\%. Menurut Suketi et al. (2010b) penambahan tingkat kematangan buah yang ditunjukkan dengan warna kuning kulit buah yang semakin banyak, akan menurunkan kandungan ATT, karena kandungan asam yang tertitrasi semakin sedikit seiring dengan proses pemasakan buah.

Hasil pengukuran kandungan vitamin $\mathrm{C}$ pepaya Sukma sebesar 98.68 sampai 134.35 mg/100 g. Hasil penelitian Putri (2016) kandungan vitamin $\mathrm{C}$ pepaya Sukma yang diperoleh sebesar 148.19 sampai $168.49 \mathrm{mg} / 100$ g. Menurut Suketi et al. (2010b) kandungan vitamin C pepaya IPB 6C sebesar $100.96 \mathrm{mg}$. Berdasarkan penelitian Suketi (2011) kandungan vitamin C pepaya IPB 9 sebesar $78.61 \mathrm{~mm} / 100 \mathrm{~g}$. Menurut Bron dan Jacomino (2006) asam askorbat dalam pepaya meningkat $20-30 \%$ selama proses pematangan dan tidak tergantung tingkat kematangan pepaya saat panen. Menurut Workneh et al. (2012) kondisi lingkungan mempengaruhi metabolisme dan penyerapan nutrisi mineral oleh tanaman, karena tingkat transpirasi meningkat dengan meningkatnya suhu. 


\section{KESIMPULAN}

Pola tanaman sela sayuran-pepaya dapat meningkatkan produktivitas lahan. Perlakuan tanaman Basella alba menghasilkan produksi yang tinggi pada tanaman sayuran. Perlakuan tanaman bayam menghasilkan bobot buah per petak yang tinggi pada tanaman pepaya sedangkan tanaman kangkung menghasilkan bobot per buah terendah. Perlakuan tanaman sela diantara tanaman pepaya tidak mempengaruhi pertumbuhan, mutu fisik dan mutu kimia buah pepaya.

\section{DAFTAR PUSTAKA}

[Balitsa] Balai Penelitian Tanaman Sayuran. 2007. Budidaya Tanaman Sayuran. Lembang, Bandung.

Barus, A., Syukri. 2008. Agroteknologi Tanaman Buah-buahan. Medan (ID): Universitas Sumatera Utara Press.

Beets, W.C. 1982. Multiple Cropping and Tropical Farming Systems. Inggris (UK): Gower Publ Co.

[BMKG] Badan Meteorologi Klimatologi dan Geofisika. 2016. Data iklim wilayah Pasir Kuda bulan Maret-Juli 2016. Stasiun Klimatologi Darmaga, Bogor.

[BPS] Badan Pusat Statistika. 2015. Produksi tanaman buah-buahan: pepaya (ton). [internet]. [diunduh 2015 Jan 08]. Tersedia pada http://www.bps.go.id.

Bron, H.V., Jacomino, A.P. 2006. Ripening and quality of Golden papaya fruit harvested at different maturity stages. Braz. J. Plant Physiol. 18: 389-396.

Broto, W., Suyanti, Sjaifullah. 1991. Karakterisasi varietas untuk standardisasi mutu buah pepaya (Carica papaya L.). $J$. Hortikultura. 1(2):41-44.

Deell, J.R., Prange, R.K., Peppelenbos, H.W. 2003. Postharvest Physiology of Fresh Fruit and Vegetables. Di dalam: Chakraverty A., Mujumdar A.S., Raghavan G.S.V. dan Ramaswamy H.S., $(E d s)$. Handbook of Postharvest Technology. Marcel Dekker, New York. 455-483 p.
Fardilawati, N. 2008. Pengaruh perbedaan umur pohon induk terhadap karakter morfologi tanaman, kualitas, dan produksi buah pepaya (Carica papaya L.). [Skripsi]. Institut Pertanian. Bogor. Bogor.

Ferry, Y., Wardiana, E. 2012. Pengaruh jarak tanam dan jenis tanaman sela terhadap pertumbuhan lada perdu serta hasil tanaman sela. Bul. Ristri. 3(2):151-156.

Gomez, A.A., Gomez, K.A. 1983. Multiple Cropping in the Humid Tropics of Asia. International Development Research Centre, Ottawa. 248 p.

Hafsah, S., Sastrosumarjo, S., Sujiprihati, S., Sobir, Hidayat, S.H. 2007. Daya gabung dan heterosis ketahanan pepaya (Carica papaya L.) terhadap penyakit antraknosa. Bul. Agron. 35(3):197 - 204.

Jensen, E., Ambus, N., Bellostas N. 2006. Intercropping of Cereals and Grain Legumes for Increased Production, Weed Control, Improved Product Quality and Prevention of $\mathrm{N}$-losses in European Organic Farming Systems. European Joint Organic Congress, Odense, Denmark.

Kader, A.A. 1992. Postharvest Biology and Technology. Di dalam: Kader A.A., $(E d s)$. Bananas and Plantains. Postharvest Technology Horticulture Corps. Agriculture and Natural Resources Publication, University of California, California. 15-20 p.

Khumairot, F. 2014. Pertumbuhan dan produksi tomat (Lycopersicon esculantum mill.) toleran naungan pada pola tanam tumpang sari. [Skripsi]. Institut Pertanian Bogor. Bogor.

Mardhan, R., Tety, E., Tarumun, S. 2015. Optimalisasi produksi usahatani pepaya (Carica papaya L.) di kelurahan Palas kecamatan Rumbai kota Pekanbaru. Jom Faperta 2(1):1-9.

Mardiana, N. 2003. Pengkajian umur petik dan kualitas buah delapan genotipe pepaya. [Skripsi]. Institut Pertanian Bogor.

Mongdong, D.I. 2007. Pengaruh waktu panen dan pemangkasan daun jagung (Zea mays L.) pada pola tanam tumpang sari terhadap 
pertumbuhan dan produksi kacang panjang (Vigna sinensis L.). [Skripsi]. Institut Pertanian Bogor. Bogor.

Nirmalayanti, K.A., Subadiyasa, I.N.N., Arthagama, I.D.M. 2017. Peningkatan produksi dan mutu tanaman bayam merah (Amaranthus amoena Voss) melalui beberapa jenis pupuk pada tanah inceptisols, desa Pegok, Denpasar. $J$. Agroekoteknologi Tropika 6(1):1-10.

Normasari, F., Purwoko, B.S. 2002. Pengaruh pemberian $\mathrm{CaCl}_{2}$ prapanen terhadap perubahan kualitas tomat segar selama penyimpanan. Bul. Agron. 30 (2):53-57.

Pantastico, E.B. 1989. Fisiologi Pasca Panen, Penanganan dan Pemanfaatan Buahbuahan dan Sayur-sayuran Tropika dan Subtropika. Kamariyani, penerjemah. Terjemahan dari: Postharvest Physiology, Handling and Utilization Tropical and Sub-tropical Fruits and Vegetables. Yogyakarta (ID): Gajah Mada University Press.

Poerwanto, R., Susila A.D. 2014. Teknologi Hortikultura. Bogor (ID): IPB Press.

Pratiwi, H.E., Suketi, K., Widodo, W.D. 2014. Aplikasi kalium permanganat sebagai oksidan etilen dalam penyimpanan buah pepaya IPB Callina. Dalam: Kartika J.G., Suwarno W.B., Ardhie S.W., Sanura C.P.E., Fitriani F.N., $(E d s)$. Membangun Sistem Bar Agribisnis Hortikultura Indonesia pada Era Pasar Global. Prosiding Seminar Ilmiah Perhimpunan Hortikultura (PERHORTI); Bogor, Okt 9, 2013.

Putri, T.Y. 2016. Kriteria kematangan pascapanen pepaya Sukma berbasis satuan panas. [Skripsi]. Institut Pertanian Bogor. Bogor.

Ryall, A.L., Pentzer, W.T. 1982. Handling, Transportation, and Storage of Fruits and Vegetables. Second Edition Volume 2 Fruits and Tree Nuts. The Avi Publishing Company, Inc. Westport. 634 p.

Sarjoni. 2013. Pengaruh bahan organik dan waktu tanam pada hasil tumpang sari jagung dan kacang tanah.Widyariset. 16(3): 457-466.
Setiawati, W., Murtiningsih, R., Sopha, G.A., Handayani, T. 2007. Budidaya Tanaman Sayuran. Balai Penelitian Tanaman Sayuran. Lembang, Bandung.

Sugito, J. 2015. Kriteria kematangan pascapanen pepaya Callina pada umur petik dan umur tanaman berbeda. [Skripsi]. Institut Pertanian Bogor. Bogor.

Suketi, K., Widodo, W.D., Purba, K.D. 2007. Kajian Daya Simpan Buah Pepaya. Dalam: Rostini N., Nurmala T., Karuniawan A., Nuraini A., Amien S., Riswandi D, Qosim W.A., (Eds). Pengembangan dan Optimalisasi Produksi Komoditas Tanaman Pangan, Hortikultura, Perkebunan dan Bioenergi. Kongres IX Perhimpunan Agronomi Indonesia (PERAGI); Bandung, Nov 1517, 2007.

Suketi, K., Poerwanto, R., Sujiprihati, S., Sobir, Widodo, W.D. 2010a. Karakter fisik dan kimia buah papaya pada stadia kematangan berbeda. J. Agron. Indonesia 38(1): 60-66.

Suketi, K., Poerwanto, R., Sujiprihati, S., Sobir, Widodo, W.D. 2010b. Studi karakter mutu buah pepaya IPB. J. Hort. Indonesia 1(1):17-26.

Suketi, K. 2011. Studi morfologi bunga, penyerbukan dan perkembangan buah sebagai dasar pengendalian mutu buah pepaya IPB. [Disertasi]. Institut Pertanian Bogor. Bogor.

Suketi, K., Widodo, W.D., Dinarti, D., Prasetyo, H.E., Pratiwi, H.E. 2015. Efektivitas oksidan etilen terhadap daya simpan dan kualitas pascapanen buah pepaya Callina. Di dalam: Soemargono A., Muryati, Hadiati S., Martias, Sutanto A., Indriyani N.L.P. dan Jumjunindang, $(E d s)$. Dukungan Teknologi dan Hasil Penelitian dalam Membangun Pertanian Bio-industri Buah Tropika Berkelanjutan. Seminar Nasional Buah Tropika Nusantara II; Bukittinggi, Sep 23-25, 2014.

Susila, A.D. 2006. Panduan Budidaya Tanaman Sayuran. Departemen Agronomi dan Hortikultura, Fakultas Pertanian IPB, Bogor. 
Susilo, K.R., Diennazola, R. 2012. 19 Bisnis Tanaman Sayur Paling Diminati Pasar. Jakarta (ID): AgroMedia.

Suwarno, F.C., Hapsari, I. 2008. Studi alternatif substrat kertas untuk pengujian viabilitas benih dengan metode uji UKDdp. Bul. Agron. 36(1):84-91.

Taris, M.L., Widodo, W.D., Suketi, K. 2014. Kriteria kemasakan buah pepaya (Carica papaya L.) IPB Callina dari beberapa umur panen. J.Hort. Indonesia 6(3): 172176.

Widati, F.. Hidayat, I.M. 2012. Budidaya Basela sebagai Tanaman Pekarangan. Balai Penelitian Tanaman Sayur, Lembang, Bandung.

Workneh, T.S., Azene, M., Tesfay S.Z. 2012. A review on the integrated agro-technology of papaya fruit. Afr. J. Biotechnol 11(85): 15098-15110. 